\title{
SOX Section 404 Twenty Years After: Reviewing Costs and Benefits
}

\author{
Bianca Fischer ${ }^{1}$, Bernadette Gral $^{1}$, Othmar Lehner*,2 \\ ${ }^{1}$ University of Applied Sciences Upper Austria \\ ${ }^{2}$ Said Business School, University of Oxford; Hanken School of Economics, Helsinki, Finland
}

\section{ARTICLE INFO}

\section{Article history:}

Resubmission 10 December 2019

Revised 15 February 2020

Accepted 16 April 2020

Published 27 May 2020

\section{Keywords:}

Sarbanes Oxley

Section 404

Internal control

Costs of SOX

Benefits of SOX

Earnings management

Earnings quality

\begin{abstract}
Some issues of the Sarbanes Oxley Act of 2002 are still discussed controversially in literature. Thereof, Section 404 concerning internal control over financial reporting is one of the most criticized parts. This article focuses on costs and benefits of the section and impacts on earnings management. Most authors agree that compliance costs of Section 404 far outweigh its benefits. However, long-term benefits are expected. Regarding earnings management, studies show that the section has positive effects such as increased earnings quality and improved internal control systems. Although the section is heavily debated in literature, there is consensus that SOX Section 404 greatly contributed to the improvement of quality of financial reporting and of corporate governance as a whole.
\end{abstract}

\section{Introduction}

Almost 20 years after the passing of the Sarbanes-Oxley Act of 2002 (hereafter referred to as SOX) certain aspects of the legislation are still discussed controversially. One of those parts of SOX that is often debated in literature is Section 404, which is concerned with internal controls of financial reporting (Glaum et. al. 2006; McEnroe 2009; Singer/You 2011). In this article, some of the most controversial issues regarding this section are explored. The results of existing literature are summarized and compared in order to give an overview of the most critical aspects of the Section. We are primarily motivated to study these issues because of the ongoing debate about costs and benefits of implementing Section 404 and the resulting impact on earnings management.

Since the beginning of the twentieth century, a number of legislative regulations and reforms have been enacted in order to improve corporate governance in corporations (Grant 2003). Yet, the debate about corporate governance is ongoing and numerous unresolved issues persist. The origins of corporate governance go far back to the 16th century, when the first corporations came into existence (Chau 2011). Although there is no universal definition of corporate governance, the original purpose of the concept can be described as the alignment of the interests of management and shareholders (Grant 2003; Chau 2011). In this context, the agency theory is a dominant aspect in literature on corporate governance, as changes in the relationship between ownership and control imply that the stakeholders' interest might be neglected by those in control (Anderson et. al. 2007; Grant 2003). As the composition of shareholders changed over time, a broader view of corporate governance developed. In the process of managing a business, legal and ethical issues arise and call for an active role in corporate monitoring and accountability (Grant 2003; Chau 2011). Chau (2011) mentions, that the importance of corporate governance becomes clear, when

* Corresponding author.

E-Mail address: othmar.lehner@hanken.fi

ORCID: 0000-0002-3317-9604 
companies fail to perform such. He argues that misconduct of corporations can result e.g. in loss of public and investors' confidence, damage of beneficial business environment, economic instability and downturns in financial markets.

The Sarbanes-Oxley Act was one of numerous efforts to resolve the difficulties in corporate govern-ance in the US by legislating ethical behavior for publicly traded companies and auditors. The Act was passed by the US Congress in July 2002 in response to several corporate and accounting scandals of highly prominent US companies, such as Enron or WorldCom and corporate ethical failures in CPA firms such as Arthur Anderson (Rockness/Rockness 2005; Iliev 2010; Li et. al. 2010). The scandals had weakened the overall confidence in the US financial markets and severely affected the public trust in corporate reporting practices and ethical behavior of companies (Chan et. al. 2008). This was partly reflected in the development of stock market indices of large capitalization stocks such as the Dow Jones, which had fallen 36 percent in the period between May 2001 and October 2002, after steady gains in the preceding 15 years (Coates 2007; Grant 2003).

Some view the Act as the most extensive reform in the financial and corporate governance legislation since the US Securities and Exchange Acts and establishment of the Securities and Exchange Com-mission (SEC) in the 1930s (Singer/You 2011; Li et. al. 2010). Its stated purpose is "to protect investors by improving the accuracy and reliability of corporate disclosures [...]" (Sarbanes-Oxley Act 2002), thus increasing investor confidence (Bhamornsiri et. al. 2009; Iliev 2010). The law changes corporate governance and enacts several requirements for publicly traded companies, registered with the SEC. This includes US-companies as well as foreign companies listing their securities on US stock exchanges. It is administered by the SEC, which implemented rulings on requirements to comply with the law (Bhamornsiri et. al. 2009; Lander 2002). The act covers issues such as the establishment of a public company accounting oversight board (PCAOB), increased requirements for auditor independence, enhanced financial disclosure requirements, heavy penalties for securities fraud, and more corporate responsibility (Bhamornsiri et. al. 2009; Grant 2003).

One key element of SOX is Section 404, which is concerned with internal controls over financial re-porting. As mentioned above, this specific section is one of the most controversially debated provisions of SOX (Glaum et. al. 2006; McEnroe 2009; Singer/You 2011). It consists of two subsections, which outline managements' and independent auditors' responsibility in connection with internal control reporting. Section 404(a) requires public companies to assess the effectiveness of their internal controls over financial reporting annually. The CEO and CFO play a significant role in this process (Starke 2006; Bhamornsiri et. al. 2009). In addition, Section 404(b) states that the external independent auditor is required to issue an attestation report on internal control. In this report, the auditor has to provide an independent opinion as to whether the company maintained effective internal control over financial reporting. Originally, Section 404(b) furthermore required auditors to give an opinion on management's assessment of internal controls (Chan et. al. 2008; McEnroe 2009). However, this requirement has been eliminated by the PCAOB (Pubilc Company Accounting Oversight Board) Auditing Standard No. 5, which was approved by the SEC in July 2007 (Nondorf et. al. 2012; PCAOB AS5 Release 2007-005A).

Singer/You (2011) point out that in general, the implementation of SOX requirements ran smoothly. However, the execution of Section 404 posed significant challenges, which led to several delays in compliance dates and separate compliance schedules for firms based on their size (Singer/You 2011). In this context, the SEC distinguishes between accelerated filers and non-accelerated filers, defined in Rule 12b-2 under the Securities Exchange Act of 1934. Companies with a common equity public float of over $\$ 75$ million are classified as accelerated filers while non-accelerated firms must have a public float of below $\$ 75$ million since 2002 or if they were classified as accelerated filers before, below $\$ 50$ million since 2005. This distinction is relevant for example when it comes to the determination of the dates for compliance (Nondorf et. al. 2012; Bhamornsiri et. al. 2009; SEC Release 33-1942). SOX Section 404 was effective for companies meeting the definition of accelerated filers as of November 15, 2004. The compliance date for non-accelerated filers was moved several times. Finally, those firms had to comply with SOX 404(a) (management assessment) as of December 15, 2007 and SOX 404(b) (auditor attestation) as of June 15, 2010. However, since July 2010 non-accelerated filers are permanently exempted from applying Section 404(b) (auditor attestation), through the Dodd-Frank Wall Street Reform and Consumer Protection Act (SEC Release 331942; Nondorf et. al. 2012). 


\section{Controversial issues regarding SOX Section 404}

As aforementioned, a great deal of literature is concerned with the requirements, implementation and effects of the Sarbanes-Oxley Act and specifically with Section 404 of the Act. The authors conducted a study of literature concerning Section 404 of the Sarbanes-Oxley Act of 2002 in order to compare and summarize the controversial findings of existing literature related to SOX Section 404.

The search concerned articles on SOX Section 404 with a publication date no lower than 2002, whereby the focus was set on most current literature in English, as well as German journals and magazines. The search was carried out through the databases EBSCO Business Source Premier, Emerald Management Xtra, ScienceDirectCollege Edition, Sage Premier and IEEE. Sarbanes-Oxley, SOX Section 404, internal control, earnings quality, compliance costs, benefits and corporate governance were used as key words.

As mentioned above, SOX Section 404 deals with internal controls over financial reporting. The section is subdivided in two parts: 404(a) is concerned with the assessment of the effectiveness of the internal control system over financial reporting; 404(b) comprises regulations for auditors related to internal controls. The following illustration shall again display the goals of SOX Section 404 (Glaum et. al. 2006; Starke 2006):

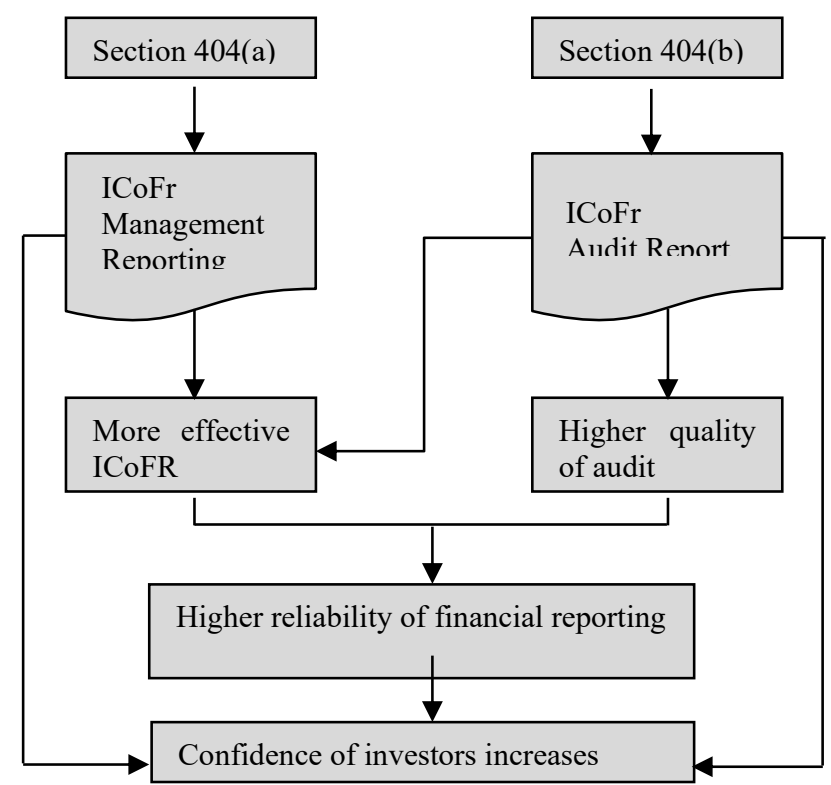

Figure 1. Goals of SOX Section 404

The regulations of Section 404(a) lead to the effect that corporations are able to install more effective internal controls because they are obligated to evaluate these controls regularly and the management has to declare its responsibility in form of a management report. The rules of Section 404(b) implicate that quality of auditing increases due to the fact that auditors are pledged to deal more intensively with internal controls over financial reporting. Summarized, higher reliability of financial reporting is achieved by more effective internal controls and by more effective auditing. As a consequence, investors' confidence in the respective company is strengthened (Starke 2006).

In the course of the literature study and review, two prominent movements were identified by the authors:

- Costs and benefits of Sarbanes-Oxley Section 404

- Sarbanes-Oxley Section 404 and earnings management

These will now be discussed in the following sections:

\section{Costs and benefits of Sarbanes-Oxley Section 404}

When examining Section 404 compliance costs, most authors undertake a classification of these costs into different categories. According to Krishnan et. al. (2008), SOX 404 costs can be classified into three categories: internal labor costs, external consulting and technology expenses and auditor attestation costs. Sneller/Langendijk (2007) prefer the categorization into assessment costs (mainly internal labor) and attestation costs, while Tackett et. al. (2006) offer a classification into monetary and non-monetary costs of compliance. Under non-monetary costs, the 
authors subsume for example logical inconsistencies and information overload. Foster et. al. (2007) divide costs into initial implementation/start-up costs and recurring monitoring costs, like audit fees.

Most detailed information in literature regarding the amount of SOX Section 404 compliance costs is available for audit fees. This is caused by the fact that audit costs represent the main part of Section 404 costs as additional auditing requirements arise (Tackett et. al. 2006; Foster et. al. 2007) and data is easily accessible. However, different results can be found in literature. Krishnan et. al. (2008) con-ducted a study and found out that total costs of compliance amount to $\$ 2.2$ million, of which $\$ 1.5$ million $(=70 \%)$ result from audit fees. Based on the data of this survey, audit fees more than doubled in the first year of compliance, compared to the year before. Eldrige/Kealey (2005; cited in Sneller/Langendijk 2007) analyzed the disclosures concerning audit fees of 648 Fortune 1000 companies. They find that the year-on-year increase between 2003 and 2004 was $65 \%$. Tackett et. al. (2006) suggest that audit fees rose by approximately $50 \%$ due to SOX Section 404. Foster et. al. (2007) present results for changes between 2003 and 2004 as well as for changes between 2004 and 2005 for companies first complying with Section 404. Increase of audit fees from 2003 to 2004 was measured to be $73 \%$, and from 2004 to 2005 the change amounted to $99 \%$. It has to be considered that between 2004 and 2005, companies that were not required to follow Section 404 experienced a rise in audit fees of $15 \%$. The following graph, one of the results of a survey by Iliev (2010), again shows that there was a significant increase in audit fees from 2003 to 2004, which is mainly due to the first compliance with Section 404:

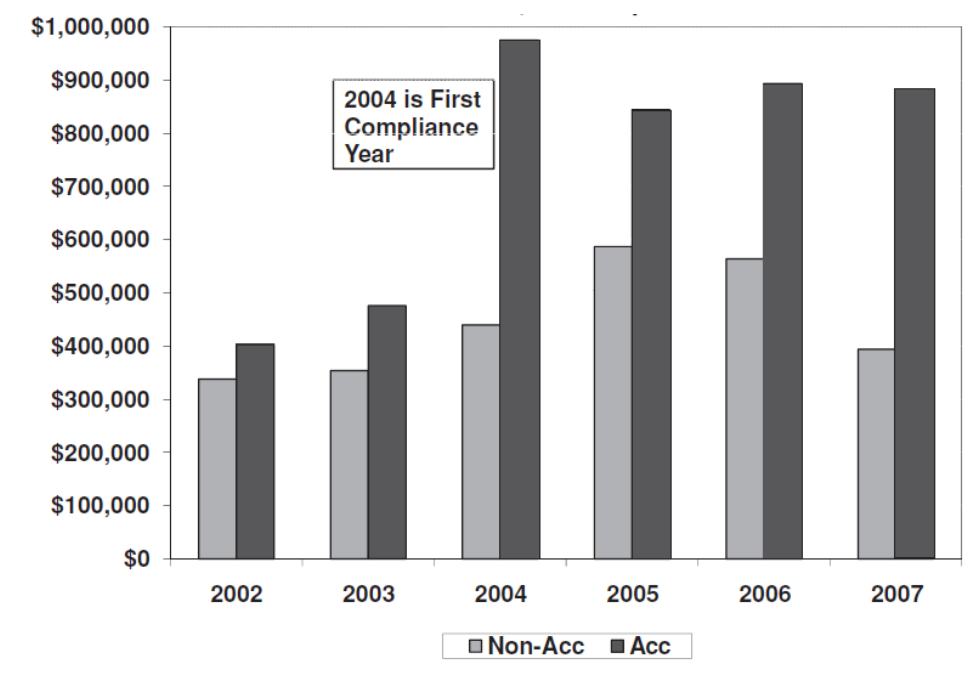

Figure 2. Increase of audit fees

In summary, it was found that there is consensus in literature about the fact that compliance costs, especially audit fees, have risen significantly since the implementation of SOX Section 404. Though, there are slight differences concerning the amount of additional costs. Furthermore, it was found that few studies with regard to total compliance costs exist, most surveys concentrate on audit fees.

It is often remarked that small corporations are disproportionately affected by the regulations of SOX Section 404 (Krishnan et. al. 2008; Iliev 2010; Ahmed et. al. 2010). To some extent, this could be attributed to the fact that smaller companies were less engaged in internal controls before SOX than larger companies and consequently were less experienced in documenting and testing internal controls over financial reporting. Additionally, surveys show that smaller companies are more likely to report internal control deficiencies than big corporations (Foster et. al. 2007).

Some authors provide options to reduce SOX Section 404 compliance costs. Sneller/Langendijk (2007) offer some cost reduction opportunities based on a case study. They suggest that Section 404 costs could be reduced by using audit staff from countries with lower rates, by using programmed controls as often as possible and by installing severity levels for the remediation of failed tests (Sneller/Langendijk 2007). Foster et. al. (2007) suggest that Section 404 compliance costs could be de-creased by reducing the frequency of audits of internal controls. After the initial auditor's report on internal controls over financial reporting, requirement of an external audit report could be less frequently (i.e. every other year), except there were reported ineffective internal controls. In addition, they are of the opinion that scaled regulations should be established for smaller corporations to save costs. Another opportunity to reduce SOX Section 404 compliance costs and increase efficiency is provided by O'Brien (2006). The author presents a top-down, risk-based approach for testing the effectiveness of internal controls over financial reporting. The process starts with the identification and evaluation of the effectiveness of company-level controls. Subsequent, significant 
accounts and related significant processes and classes of transactions are identified. In the following step, potential risks in the prior identified processes are analyzed. Concluding, controls to prevent or detect errors or fraud in these areas are determined. The author highlights that it is important to clearly link controls with the related significant accounts (O'Brien 2006a; O'Brien 2006b).

Analyses of the benefits of Section 404 of the Sarbanes-Oxley Act are found less frequently in literature. Essentially, this may be due to the fact that benefits are harder to quantify than costs (Bedard/Graham 2007). Bedard/Graham (2007) compare this incidence with the IT "productivity paradox" of the 1990s, where companies investing in IT mainly observed costs but were unable to perceive benefits of their investments. Most authors suggest that long-term benefits of Section 404 will arise eventually (Krishnan et. al. 2008; Tackett et. al. 2006). As potential benefits, reduction of long-term monitoring costs and more management time for strategic topics are named (Bedard/Graham 2007). Others claim that especially smaller companies will benefit from the implementation of Section 404 in the long run, for instance by raising capital at lower cost (Krishnan et. al. 2008). An increased comparability of financial statements among different companies due to higher uniformity of internal controls over financial reporting is also mentioned in literature (Tackett et. al. 2006).

While most authors, as aforementioned, concentrate on analyzing the costs of implementing SOX Section 404, Miller/Rittenberg (2005) conducted a study among 171 practicing internal auditors focusing on the benefits. The authors point out that many studies concerning Section 404 are incomplete. First, they do not address benefits of the section, on the one hand regarding internal control improvements and on the other hand with regard to positive effects on investors' confidence. Second, they fail to consider the learning curve and therefore neglect the fact that future Section 404 compliance costs will decrease. As reasons for the decline of costs, Miller/Rittenberg name the following:

- The initial investment for regaining investors' and public confidence has already been made.

- Cost will decrease as a result of the learning curve.

- Control processes usually become more efficient over time by applying process improvement methodologies.

Focusing on the benefits of SOX Section 404, the following graph shows the results of the survey by Miller/Rittenberg:

\section{Controls have improved due to Section 404}

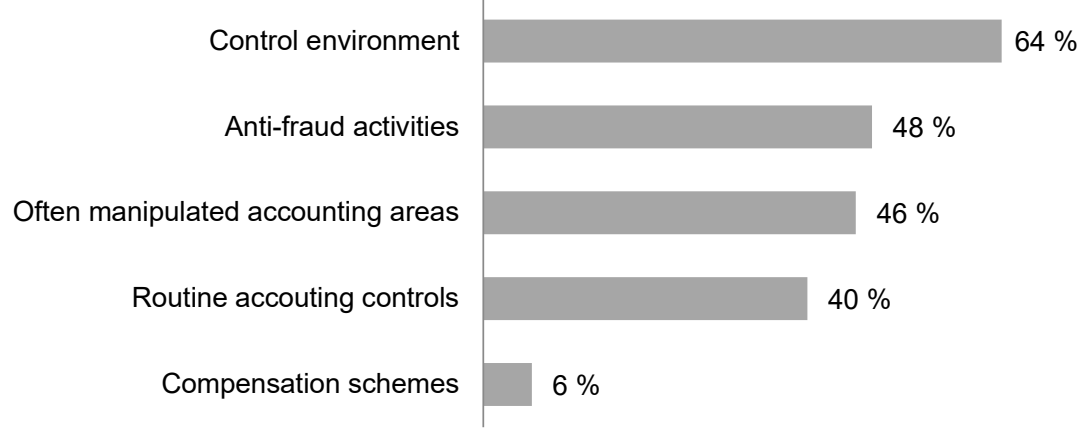

Figure 3. Improvement of internal controls

The graph shows the percentage of respondents who strongly agreed or agreed that improvements have been accomplished in the named fields. Each field (except anti-fraud activities and compensation schemes) consists of different subcategories. Concerning the control environment category, more than $70 \%$ of the participants indicated that involvement and knowledge of the audit committee has improved, as well as the monitoring of controls. In addition, improvements in the knowledge of the board and its role regarding controls were identified. Prior to SOX, many companies had not implemented effective anti-fraud processes. As a result, almost half of the study participants observed significant improvement in this field. Concerning improvements in often manipulated accounting areas, closing process and unusual journal entries were named by $62 \%$ of the respondents. Regarding routine accounting controls, the greatest benefit was identified in the record retention/audit trail area. The question concerning compensation schemes is included in the survey because fraud is often motivated by compensation. The majority of participants did not believe that there were significant improvements regarding compensation resulting from SOX Section 404 (Miller/Rittenberg 2005). 
Miller/Rittenberg (2005) did not only investigate benefits of SOX Section 404, but also costs of compliance. They discovered that $72 \%$ of the survey respondents believe that in the first year of complying with Section 404, costs exceed benefits. Additionally, the authors surveyed the prognosis of the cost-benefit ratio beyond the first year and found out, that the portion of participants believing that benefits will exceed costs represents the majority. More detailed results are displayed in the graph below:

\section{Prognosis of cost-benefit ratio}

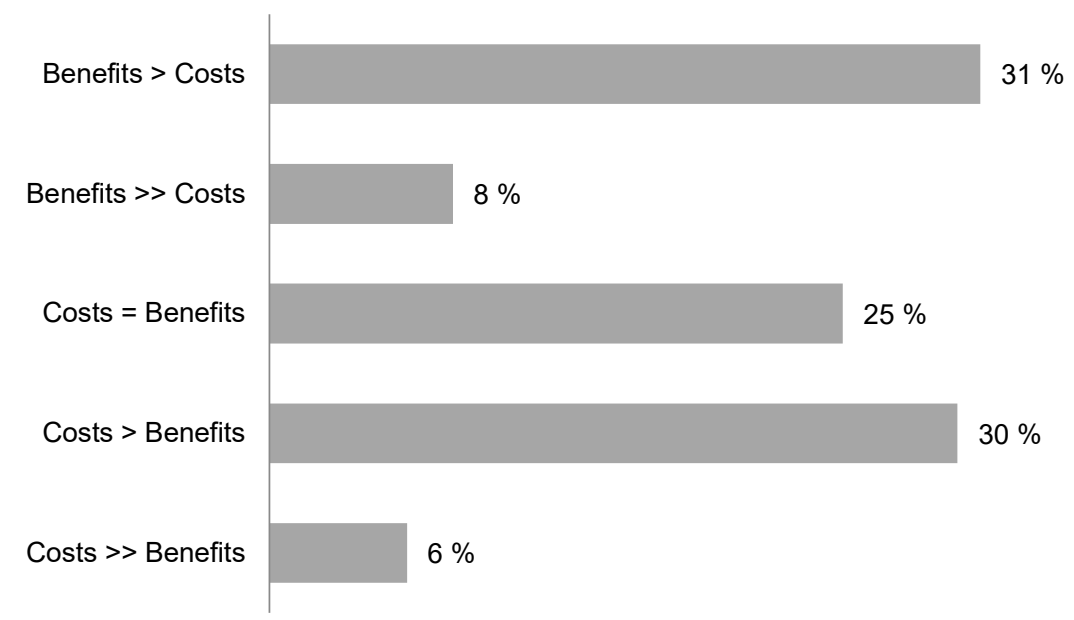

Figure 4. Prognosis of cost-benefit ratio

In summary, it can be said that the overwhelming majority of authors is of the opinion that at this stage, compliance costs exceed the benefits of SOX Section 404. However, it was found that most authors agree that there will be longterm benefits. It is suggested, that without SOX Section 404, many corporations would not have identified and remediated material weaknesses in their internal control system. Ji (2020) for example, examines whether managers in firms reporting material internal control weaknesses (ICW) under Section 404 of the Sarbanes-Oxley Act (SOX) of 2002 engage in myopic behaviors more than those in firms without reporting ICW. She finds a positive association between internal control weaknesses reported by auditors under Section 404 of the SOX and managerial shorttermism. It can thus be stated that SOX indeed contributed and contributes to the quality improvements of financial reporting and of corporate governance as a whole (Foster et. al. 2007).

\section{Sarbanes-Oxley Section 404 and earnings management}

Current literature regarding the association of SOX Section 404 requirements with earnings management can be divided in three subcategories. A number of authors investigate the effect of internal control requirements on earnings quality by comparing firms that have to comply with the regulations of Section 404 with non-complying firms (Iliev 2010; Singer/You 2011). The second subcategory contains studies that focus on the association between ineffective internal controls according to Section 404 and earnings management, by comparing firms reporting internal control weaknesses under Section 404 of SOX to firms without reported internal control weaknesses (Chan et. al. 2008; Epps/Guthrie 2010). Finally there are some studies that examine the relationship between earnings quality and internal control regarding the requirements of Section 404 as well as Section 302 of SOX (Bedard 2006; Doyle et. al. 2007). Another distinction within current literature regarding this topic could be made in respect to the measures that are used to determine earnings quality. The majority of studies focus on changes in discretionary accruals (Chan et. al. 2008), absolute accruals (Iliev 2010) or accrual estimation errors (Doyle et. al. 2007; Singer/You 2011). The authors of this article will focus on the former distinction, as it is best suited to compare the results of the respective studies.

Falling under the first subcategory, Singer/You (2011) investigate the effect of SOX Section 404 on overall quality and usefulness of reported earnings by taking into account all complying firms and comparing them to a control group of Canadian firms, which are dual listed or only listed in the US. They highlight that it is particularly important to include all complying firms instead of only those reporting internal control deficiencies, because all the affected firms bear the high compliance costs of SOX and should therefore be considered in a complete and unbiased investigation about the effect of the regulation. Similarly, Iliev (2010) concentrates on companies that have to file a management 
report under SOX 404 regulations, regardless of whether they reported internal control weaknesses or not. However, he puts a particular focus on small firms with a public float between $\$ 50$ and $\$ 100$ million in 2004. He argues that the effect of SOX on small firms is particularly interesting, since former studies showed disproportionately high costs for those firms (Ahmed et. al. 2010; Krishnan et. al. 2008).

The second subcategory includes studies of Chan et. al. (2008) as well as Epps/Guthrie (2010), who examine the effects of internal control weaknesses on earnings management. Both studies focus on companies that disclosed at least one material weakness in internal controls in 2004 and compare them to firms without reported internal control weaknesses under SOX Section 404. Epps/Guthrie (2010) reason that the regulation concerning internal control over financial reporting is designed to provide reasonable assurance regarding the reliability of financial reporting. Hence, if internal control weaknesses exist, the reliability of financial reporting is reduced and the firm's internal control system cannot be considered effective. Chan et. al. (2008) further argue, that weak controls such as an inad-equate control environment and inadequate financial procedures frequently lead to unintentional ac-counting errors as well as intentional earnings management, since more opportunities for earnings management arise.

As mentioned above, Singer/You (2011) study the effect of SOX Section 404 on overall quality and usefulness of reported earnings. They use two characteristics of earnings quality, namely reliability and relevance of reported earnings. With the magnitude of abnormal accruals acting as a proxy, the authors find significantly larger increase in earnings reliability for complying firms after the implementation of SOX. After taking into account the asymmetry between the use of negative and positive special items, they further suggest that this increase in reliability among complying firms is due to reduced intentional misstatement. Iliev's (2010) study is conducted in a broader context, as he explores Section 404 regarding (1) its costs in terms of additional audit fees, (2) its benefits in terms of better earnings quality after SOX, and (3) its net effect in terms of stock returns. By examining the distribution of firms' earnings per share and firms' accruals and discretionary accruals he finds that due to SOX Section 404, firms lost some of their discretion in reporting earnings, for which reason their ability to report positive earnings is reduced. According to his results, this fact cannot be explained by increased audit fees alone. Consequently, Iliev (2010) claims that the passage of Section 404 led to more conservative earning reports and less earnings management.

In order to determine whether the decline in abnormal accruals is associated with higher or lower earn-ings relevance, Singer/You (2011) examine the changes in predictive power of current earnings over future earnings and future cash flows. They find a significantly larger improvement of predictive power of earnings for complying firms, which suggests an increase in relevance of reported earnings. Likewise, Iliev (2010) implies that due to the fact that management has less discretion when reporting performance under SOX Section 404, reported earnings better reflect actual economic profit of firms.

Chan et. al. (2008) focus on the question whether firms reporting material internal control weaknesses under SOX 404 have more earnings management compared to other firms. The authors present mild evidence that firms with internal control weaknesses generally have more positive and absolute discretionary accruals than other firms, which indicates that earnings management is more common among those firms. The authors further suggest that the reported earnings of firms with internal control errors are biased upwards by manipulation. Epps/Guthrie's (2010) research is closely related to this paper, since the authors also investigate the effect of material weaknesses in internal controls on the extent that earnings are manipulated by using discretionary accruals. In contrast to Chan et. al. 's (2008) findings, the authors' results show that the presence of material weaknesses in internal control is connected with higher negative discretionary accruals. Therefore they claim that firms reporting internal control weaknesses engage in downward earnings management instead of upwards earnings management as suggested by Chan et. al. (2008).

In a next step, Epps/Guthrie (2010) divide discretionary accruals in three categories, namely high neg-ative, high positive, and low accruals, in order to examine the behavior of the accruals with the great-est magnitudes. The authors suggest that companies with material weaknesses in internal control and high negative (positive) discretionary accruals have significantly greater negative (positive) discretion-ary accruals than similar companies without internal control weaknesses. In other words, in firms with internal control weaknesses and high accruals, those accruals are on average larger than in other firms. Similar to Chan et. al. (2008), they conclude that weaknesses in internal controls can lead to larger absolute discretionary accruals due to failure of controls designed to limit managements' ability to manage earnings. Furthermore, they specify that the existence of internal control weaknesses al-lows for greater manipulation of earnings, regardless of the direction.

Chan et. al. (2008) additionally conduct analyses on the effects of internal control weaknesses on earnings management by classifying the firms with reported internal control weaknesses into several sub-samples. Amongst other things, they find that firms which had to issue a restatement of their financial statements tend to have more absolute discretionary accruals whereas firms without do not have significant discretionary accruals. Furthermore, the authors state that firms with multiple internal control weaknesses tend to have more absolute discretionary 
accruals than firms with fewer or only one material weakness. The results of the sub-sample analyses are consistent with the finding that firms with internal control weaknesses tend to have more earnings management. Chan et. al. (2008) conclude that SOX Section 404 brought the potential benefit of improved earnings quality, as it is likely that firms amend their internal controls after auditors found internal control weaknesses in their assessment according to Section 404. Besides, Epps/Gurthie (2010) point out that 39\% of the material weakness companies are concentrated in the two industries business services and electronic, and electrical equipment and components. Consequently, they suggest that those industries should be given particular attention by auditors assessing internal controls.

While most authors concentrate solely on studying SOX Section 404 in connection with earnings man-agement, others take into account Section 302 of SOX as well (Bedard 2006; Doyle et. al. 2007). Those studies form the third subcategory, whose results will be discussed in the following part of this article.

Section 302 of the Sarbanes-Oxley Act requires management to certify the financial statements of the company and to report any material changes in their internal controls in the quarterly or annual reports (Bedard 2006). There is a substantial overlap between a company's disclosure controls and proce-dures (Section 302) and its internal control over financial reporting (Section 404). However, there are some aspects in which the requirements differ (SEC Release 33-8238). The most obvious difference is the increased level of scrutiny under Section 404. Although Section 302 of SOX requires management to report the effectiveness of disclosure and control procedures, an auditor's assessment report is not necessary (Doyle et. al 2007). Furthermore, under Section 302 the content of disclosure is left to management's judgment and disclosure of reasons for changes in internal controls is not mandatory (Bedard 2006).

Bedard (2006) examines whether the requirements of Section 302 and 404 of SOX are associated with improved earnings quality. Similar to Epps/Guthrie (2010) and Chan et. al. (2008), the author focuses on companies that disclosed at least one internal control weakness. Bedard finds that the level of unexpected accruals increases in the year internal control weaknesses are disclosed, which implies increased earnings quality. She suggests that in the year of disclosure of an internal control weakness, management reverses prior accruals that were too large. Likewise, Doyle et. al. (2007) confirm that weak internal controls are associated with relatively low-quality accruals, measured in accrual estimation errors. Besides, the authors add that firms with company-level material weaknesses have lower accruals quality than firms with account-specific material weaknesses, since auditors are likely to detect and correct those weaknesses prior the issuance of the financial statements.

When comparing SOX Section 302 and Section 404 requirements, Bedard (2006) shows that the magnitude of unexpected accruals is larger for Section 302 disclosures. The author concludes that the nature and significance of those weaknesses is probably more severe and primarily caused by the discovery of a material misstatement. In addition, Bedard (2006) states that while Section 302 disclo-sures are associated with lower positive accruals, Section 404 disclosures result in no significant change of accruals. Hence, she implies that for Section 302 disclosures large prior years' accruals result from income increasing bias, whereas Section 404 disclosures result mainly from errors caused by difficulties in estimating accruals. Doyle et. al (2007) agree that material weakness disclosure under Section 302 is more strongly associated with lower earnings quality, while disclosure under Section 404 does on average not lead to poorer earnings quality. However, they point out that when disclosures are broken down into account-specific and company-level weaknesses, company-level Section 404 weaknesses are linked to poorer accruals quality. Bedard (2006) finally concludes that the SOX Section 404 internal control assessment process causes firms to improve their internal controls and auditors to increase their effort, resulting in an increase in earnings quality.

Overall, it can be said that the authors of all three mentioned subcategories agree on the fact that the passage of SOX Section 404 brought the potential benefit of improving earnings quality in complying firms. While some highlight that the requirements of Section 404 resulted in more conservative earning reports and less earnings management (Iliev 2010; Singer/You 2011), others imply that firms improve their internal controls after auditors find internal control weaknesses in their assessment according to Section 404 (Bedard 2006; Chan et. al. 2008; Epps/Guthrie 2010). On the other hand, there are still some effects of SOX Section 404 on which authors disagree, such as the question if firms reporting internal control weaknesses rather engage in downward earnings management or in upwards earnings management (Chan et. al. 2008; Epps/Guthrie 2010).

\section{Conclusion}

The Sarbanes-Oxley Act was passed in 2002 in response to numerous high-profile corporate and accounting scandals of well-established companies in the US, which can be seen as a result of a world-wide crisis in corporate governance. The primary goal of the Act is to protect investors and increase their confidence in corporations after all these scandals by improving the reliability of corporate disclosures. This article focuses on one of the most controversially debated 
sections of SOX: Section 404, concerning internal controls over financial reporting. The section is subdivided in two parts. Section 404(a) deals with the evaluation of the effectiveness of the internal control system over financial reporting, while Section 404(b) is concerned with external audit requirements for the internal controls over financial reporting.

Initially, SOX had broad support by corporations as well as by the public. However, since the implementation of the Act in corporations, critics concerning compliance costs have appeared. Especially costs in connection with Section 404 are regarded as greatly exceeding the achieved benefits. An analysis of existing literature shows that audit fees rose significantly due to the implementation of SOX Section 404. However, different numbers regarding the amount of increase of audit fees can be found. The amount reported in literature ranges between $73 \%$ (Foster et. al. 2007) and approximately $50 \%$ (Krishnan et. al. 2008; Tackett et. al. 2006; Iliev 2010). Suggested options to reduce SOX Section 404 compliance costs are, using audit staff from countries with lower rates and programmed controls wherever possible (Sneller/Langendijk 2007) and reducing the frequency of audits of internal controls (Foster et. al.). Analyses of the benefits of Section 404 are found less often in literature, which may mainly be due to the fact that benefits are harder to quantify than costs (Bedard/Graham 2007). Still, most authors suggest that long-term benefits will arise. A study by Miller/Rittenberg (2005) regarding benefits of SOX Section 404 is described in detail in the present article. Results of the study demonstrate that improvements, especially concerning the control environment, antifraud activities and manipulated accounting areas could be achieved through SOX Section 404. Furthermore, the study comprises a prognosis of the cost-benefit ratio, which states that it is expected that benefits will exceed costs in the future. Although costs of implementing SOX Section 404 are high, it is suggested in literature that the regulations greatly contributed to the improvement of the quality of financial reporting.

In the second part of the article, current literature regarding the impact of SOX Section 404 on earnings management is analyzed. Overall, there is consensus in literature that due to the implementation of Section 404, earnings quality has improved in complying firms, though some conflictive statements were found. It should be noted that different samples were used in the discussed studies to investigate the association of Section 404 and earnings management. Some authors examined the impact on earnings management in all firms which have to comply with the regulation. Thereof, Iliev (2010) remarks that the enactment of SOX Section 404 resulted in more conservative earning reports and less earnings management. Comparably, Singer/You (2011) report an increase in reliability of earnings and reduced intentional misstatement due to Section 404. Others studied earnings management in firms, which reported internal control weaknesses under SOX Section 404. Chan et. al. (2008) reason that Section 404 leads to general improvements in internal control, following the revelation of an internal control weakness. They furthermore suggest that upwards earnings management is found more frequently in firms reporting material internal control weaknesses, while the results of Epps/Guthrie (2010) imply that firms reporting material internal control weaknesses engage in downwards management. Additionally, Epps/Guthrie (2010) found that in companies reporting internal control weaknesses and displaying high accruals, those accruals are larger compared to other corporations. There are some studies that do not only take into account SOX Section 404 but also Section 302, which requires management to certify the financial statements and to report material changes in the internal control system. Bedard (2006) found that Section 404 disclosures do not result in significant changes of accruals, while Section 302 disclosures lead to lower positive accruals. Moreover, Doyle et. al. (2007) reason that disclosures of material weaknesses under Section 302 are stronger associated with lower earnings quality than disclosures under Section 404. Although most authors agree that the requirements of SOX Section 404 generally place a heavy burden on complying firms, current studies confirm that the Section has positive impacts such as decreased earnings management, increased quality of reported earnings as well as improved internal controls.

During their analysis of current literature, the authors discovered potential areas of future research concerning SOX Section 404. The lack of literature on specific and measurable benefits of Section 404 indicates that more detailed research is needed in this field. As pointed out, current authors are mostly in agreement that compliance costs of Section 404 exceed its benefits, whereby it is frequently stated that long-term benefits are expected. Hence, the quantification of benefits and compliance costs of Section 404 should be examined more closely. Furthermore, the outcomes of this literature study confirmed that Section 404 is one of the most controversial parts of the SarbanesOxley Act. Consequently, another potential aspect of research would be on possible amendments of the section.

\section{References}

Anderson, D.W., Melanson, S.J. \& Maly, J. (2010). The Evolution of Corporate Governance: power redistribution brings boards to life. Corporate Governance: an international review, 15(5), 780-797. 
Bedard, J. C. (2006). Sarbanes Oxley Internal Control Requirements and Earnings Quality. Available at SSRN: http://papers.ssrn.com/sol3/papers.cfm?abstract_id=926271

Bedard, J. C. \& Graham, L. E. (2007). Sarbanes Oxley Section 404 and Internal Controls. The CPA Journal, 86(3), $34-37$.

Bhamornsiri, S., Guinn, R. \& Schroeder, R. G. (2009). International Implications of the Cost of Compliance with the External Audit Requirements of Section 404 of Sarbanes-Oxley. International Advances in Economic Research, 15(1), 17-29.

Chan, K. C., Farrell, B. \& Lee, P. (2008). Earnings Management of Firms Reporting Material Internal Control Weaknesses under Section 404 of the Sarbanes-Oxley Act. Auditing: A Journal of Practice \& Theory, 27(2), 161-179.

Chau S.L. (2011). An Anatomy of Corporate Governance. IUP Journal of Corporate Governance, 10(1), 7-21.

Coates, J. (2007). The goals and promise of the Sarbanes Oxley Act. Journal of economic perspec-tives, 21(1), 91-116.

Doyle, J. T., Ge, W. \& McVay, S. (2007). Accruals Quality and Internal Control over Financial Reporting. The Accounting Review, 82(5), 1141-1170.

Epps, R. W. \& Guthrie C. P. (2010). Sarbanes-Oxley 404 material weaknesses and discretionary accruals. Accounting Forum, 34(2), 67-75.

Foster, B. P., Ornstein, W. \& Shastri, T (2007). Audit costs, material weaknesses under SOX Section 404. Managerial Auditing Journal, 22(7), 661-673.

Glaum, M., Thomaschweski, D. \& Weber, S. (2006). Auswirkungen des Sarbanes-Oxley Acts auf deutsche Unternehmen: Kosten, Nutzen, Folgen für US-Börsennotierungen. Studien des Deutschen Aktieninstituts.

Grant, G. H. (2003). The evolution of corporate governance and its impact on modern corporate America. Management Decision, 41(9), 923-934.

Gunz, S., \& Thorne, L. (2019). Thematic Symposium: Accounting Ethics and Regulation: SOX 15 Years Later.

Iliev, P. (2010). The Effect of SOX Section 404: Costs, Earnings Quality, and Stock Prices. The Journal of Finance, LXV(3), 1163-1196.

Ji, A.E. (2020). Internal Control Weakness and Managerial Myopia: Evidence from SOX Section 404 Disclosures, ACRN Journal of Finance and Risk Perspectives, 8(1), 71-83.

Krishnan, J., Rama, D. \& Zhang, Y. (2008). Costs to comply with SOX Section 404. Auditing: A Journal of Practice \& Theory, 27(1), 169-186.

Kwon, S. H., \& Deshmukh, A. (2019). Earnings management and instances of material weaknesses reported under Sections 302 and 404. Asia-Pacific Journal of Accounting \& Economics, 1-20.

Lander, G. P. (2002). The Sarbanes Oxley Act of 2002. The Journal of Investment Compliance, 3(1), 44-53.

Lehner, O. M. (2012). Social entrepreneurship perspectives. Triangulated Approaches to Hybridity, University of Jyväskylä.

Li, C., Sun, L. \& Ettredge, M. (2010). Financial executive qualifications, financial executive turnover, and adverse SOX404 opinions. Journal of Accounting and Economics, 50(1), 93-110.

Lyubimov, A., Davis, L., \& Trompeter, G. (2020). The impact of the Sarbanes-Oxley Section 404 (b) exemption on earnings informativeness. International Journal of Auditing, 24(1), 3-23.

Miller, P. K. \& Rittenberg, L. E. (2005) Sarbanes-Oxley Section 404 Work - looking at the benefits. www.theiia.org/research

McEnroe , J. E. (2009): CFOs' and public accountants' perceptions of material weaknesses in internal control areas as required by Section 404 of the Sarbanes-Oxley act. Research in Accounting, 21(1), 48-55.

Nondorf, M. E., Singer, Z. \& You, H. (2012). A study of firms surrounding the threshold of Sarbanes-Oxley Section 404 Compliance. Advances in Accounting, In Press, Corrected Proof, Available online 3 March 2012

O'Brien, P. (2006a). Reducing SOX Section 404 Compliance Costs Part 1. The CPA Journal, 26-28

O'Brien, P. (2006b). Reducing SOX Section 404 Compliance Costs Part 2. The CPA Journal, Available at http://www.nysscpa.org/printversions/cpaj/2006/806/p36.htm

Rockness, H. \& Rockness, J. (2005). Legislated ethics: From Enron to Sarbanes-Oxley, the impact on corporate America. Journal of Business Ethics, 57, 31-54.

Schroeder, J. H., \& Shepardson, M. L. (2016). Do SOX 404 control audits and management assessments improve overall internal control system quality?. The Accounting Review, 91(5), 1513-1541.

Singer, Z. \& You, H (2011). The Effect of Section 404 of the Sarbanes-Oxley Act on Earnings Quality. Journal of Accounting, Auditing \& Finance, 26(3), 556-589.

Sneller, L. \& Langendijk, H. (2007). Sarbanes Oxley Section 404 Costs of Compliance: a case study. Corporate Governance: an international review, 15(2) 101-111.

Starke, P. (2006). Section 404 des Sarbanes-Oxley Act - Eine Untersuchung ihrer Auswirkungen auf Rechnungslegung, Abschlussprüfung und den Kapitalmarkt. Dissertation.

Tackett, J. A., Wolf, F. \& Claypool, G. A. (2006). Internal control under Sarbanes-Oxley: a critical examination. Managerial Auditing Journal, 21(3) 317-323.

Weber, D. P., \& Yang, Y. S. (2020). The debt-equity choice when regulatory thresholds are based on equity values: Evidence from SOX 404. The Accounting Review, 95(2), 339-364.

(C) 2020 by the authors. Licensee ACRN Publishing, Austria, Editor in Chief Prof. Dr. Othmar M. Lehner. This article is an open access article distributed under the terms and conditions of the Creative Commons Attribution (CC BY SA) license 
B. Fischer, B. Gral, O. Lehner / ACRN Journal of Finance and Risk Perspectives 9 (2020) 103-112

(https://creativecommons.org/licenses/by-sa/4.0/) 